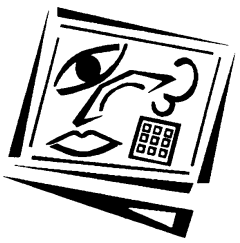

\title{
Educational design of short, audio-only podcasts: The teacher and student experience
}

Lucy Taylor

The University of Sydney

Steve Clark

The Royal College of Pathologists of Australasia

\begin{abstract}
This paper reports the findings of an exploratory study on the use of podcasting in higher education. The study was conducted during 2007 and 2008 and involved students from 20 units of study. Research data was gathered by distributing an in-class survey to 4584 enrolled students, with $39 \%$ (1780) of students completing the survey. Qualitative data was gathered by conducting student focus groups, with a total of 158 students participating, and interviewing teaching staff on their podcasting experiences. The results identified three broad approaches to podcasting employed: reframed podcasts, or content reproduced in multiple media (e.g., textbook chapters summarised as podcast episodes); complementary podcasts that added extra information to enhance the student learning experience; and supplementary podcasts that re-design and broadcast content previously presented in class.
\end{abstract}

\section{Introduction}

With each new technology created and disseminated into the global market today, there is a rush by academics to find novel ways to implement and apply these devices in their learning and teaching. Many technologies were not originally intended or designed to be used in the educational field and are often referred to as "edutainment devices" (Egenfeldt-Neilsen, 2005 as cited in Wheeler, 2009). Wheeler (2009) identified 3 common edutainment devices: iPods, global positioning systems, and smart phones not developed for learning, emphasising that "academics require a good understanding of potential teaching applications" if these devices are to be successfully re-purposed into a learning and teaching context. This is especially important given the ongoing debate and scepticism around new technologies being integrated into learning and teaching, especially when applied in a blended learning context.

In this paper we present a research study on the possible approaches that academics may take when using podcasting, a means of creating digital resources that is gaining momentum and usage in higher education. Podcasting provides teaching staff with a means to communicate with students by broadcasting a series (a podcast) of multimedia files (podcast episodes) via the Internet, to which students may subscribe. Using audio, or even multimedia, in learning and teaching is not a recent development (Gunn, Woodgate \& O'Grady, 2005; Lee, McLoughlin \& Chan, 2007; Schlosser \& Burmeister, 2006). Nor is RSS (Really Simple Syndication), that which controls the connection of multiple podcast episodes into one subscription, as it has been in use for 
more than a decade and is broadly used by other Internet tools today (Ebner, Nagler \& Saranti, 2007; Franklin \& Zdonik, 1998). A podcast, then, is unique because it is a combination of these things: a multimedia file, a subscription service and a downloadable (and therefore potentially mobile) digital file. The podcasting process remains the same for most scenarios, whether the podcast is for a radio series, a regular community group announcement or an academic lecture series. Podcasting is therefore a process that can be applied to a variety of situations with many different approaches.

To determine the effectiveness of differing podcasting approaches used by teaching staff participating in this research, we gathered data on the perceived impact of podcasting on the learning and teaching experience, focusing on four key research questions:

1. What are the different approaches to podcasting to students used by teaching staff?

2. Does the podcasting approach impact the students' use of the podcast?

3. What perceived benefit did the podcast have for learning and teaching?

4. Do students and lecturers like podcasting, and would they like more podcasting for university purposes?

By answering the above research questions, evidence of student perceptions about how different podcasting approaches impact their learning experience will inform the development of guidelines for effective uses of podcasting.

\section{Background}

The research study was conducted in the Faculty of Economics and Business at the University of Sydney during 2007 and 2008. It was undertaken in response to a growing number of teaching staff requesting support for the creation of audio-only resources for their students.

At the beginning of this project, many studies about the use of podcasting in higher education referred to lecture recording (for example, Aldrich, Bell \& Batzel, 2006; Brittain, Glowacki, Ittersum \& Johnson, 2006; Tynan \& Colbran, 2006) and some podcasting studies focused on providing students with hardware (Belanger, 2005; Shannon, 2006). Putting material designed for the classroom onto a learning management system (e.g., recorded lectures, presentation slides, etc.) will not necessarily reap benefits for students or teaching staff because technology use and learning are not synonymous (Henry \& Meadows, 2008). It is therefore important to think about how technologies are used to support or enhance learning and teaching. In light of this and with the limited information available about pedagogically-sound approaches to podcasting, and many local teaching staff's mistrust of lecture recording, the focus of this study became the use of short, audio-only podcasts. After discussions about potential podcasting approaches, coordinators of twenty units of study accepted an invitation to participate during four semesters in 2007-2008.

Studies involving short podcast episodes increased during the course of this study, as educators considered podcasting options other than lecture recording (for example, Bell, Cockburn, Wingkvist \& Green, 2007; Calder, 2006; Chan, Lee \& McLoughlin, 2006; Edirisingha \& Salmon, 2007). In this study, teaching staff took different approaches to the type of podcast they created, based on a perceived pedagogical benefit they 
thought the medium could provide. For example, one lecturer podcast a series of short, 3-5 minute episodes that presented the context of the theories discussed in the next week's readings. This information was previously presented in the lecture, however the lecturer felt that students were too exhausted at the end of a three-hour seminar to concentrate on the new topic. The podcast meant that students could get the supplementary information as it suited them. These variations provided an opportunity to analyse the different approaches, in conjunction with student feedback, and in the context of the podcast's pedagogical purpose.

\section{Methodology}

The participating twenty units of study were chosen on a sequential sampling basis (Neuman, 2006, p. 224), that is, the maximum units of study that the researchers could feasibly support and evaluate (around five per semester). Student and lecturer participation in the study was wholly voluntary in compliance with University of Sydney ethics guidelines. Participating lecturers were given a 30 minute technical training session on how to create a podcast and use a microphone headset. While a technical support officer was available to assist the lecturers, in the majority of cases, no further assistance was required.

The number of students enrolled varied from 26 to 783 per unit of study, with a total of 4584 enrolled students. From the total number of enrolled students, 39\% (1780) participated in the study (Table 1). Units of study ranged across six disciplines in the Faculty, and included both undergraduate and postgraduate levels. The average number of episodes per podcast was 7, and the average length for each podcast episode was 11 minutes (Table 1).

Table 1: Sample

\begin{tabular}{|c|c|c|c|c|c|c|}
\hline Year & Enrolled & Level & $\begin{array}{c}\text { Episodes per } \\
\text { podcast }\end{array}$ & $\begin{array}{l}\text { Average length of } \\
\text { episode (mins) }\end{array}$ & $\begin{array}{l}\text { Survey } \\
\text { return rate }\end{array}$ & $\begin{array}{l}\text { Focus group } \\
\text { participant rate }\end{array}$ \\
\hline \multirow[t]{10}{*}{2007} & 112 & Postgrad & 4 & 6 & $64 \%$ & $3 \%$ \\
\hline & 26 & Undergrad & 5 & 6 & $92 \%$ & $38 \%$ \\
\hline & 74 & Postgrad & 9 & 9 & $76 \%$ & $11 \%$ \\
\hline & 85 & Postgrad & 6 & 10 & $66 \%$ & $2 \%$ \\
\hline & 570 & Undergrad & 12 & 11 & $21 \%$ & $2 \%$ \\
\hline & 783 & Postgrad & 6 & 11 & $27 \%$ & $0 \%$ \\
\hline & 421 & Undergrad & 4 & 15 & $45 \%$ & $1 \%$ \\
\hline & 308 & Undergrad & 3 & 20 & $6 \%$ & $3 \%$ \\
\hline & 67 & Postgrad & 3 & 24 & $67 \%$ & $15 \%$ \\
\hline & 30 & Postgrad & 4 & 7 & $67 \%$ & $13 \%$ \\
\hline \multirow[t]{10}{*}{2008} & 428 & Undergrad & 15 & 4 & $33 \%$ & $2 \%$ \\
\hline & 88 & Postgrad & 12 & 11 & $41 \%$ & $18 \%$ \\
\hline & 20 & Undergrad & 7 & 16 & $60 \%$ & $40 \%$ \\
\hline & 27 & Postgrad & 6 & 8 & $85 \%$ & $59 \%$ \\
\hline & 47 & Postgrad & 6 & 6 & $83 \%$ & $19 \%$ \\
\hline & 71 & Postgrad & 9 & 16 & $80 \%$ & $11 \%$ \\
\hline & 140 & Postgrad & 2 & 14 & $76 \%$ & $7 \%$ \\
\hline & 393 & Undergrad & 14 & 2 & $45 \%$ & $0 \%$ \\
\hline & 305 & Postgrad & 3 & 11 & $88 \%$ & $3 \%$ \\
\hline & 589 & Undergrad & 13 & 11 & $18 \%$ & $1 \%$ \\
\hline Total & 4584 & & & & $39 \%$ & $3 \%$ \\
\hline
\end{tabular}


The instruments included paper surveys, focus groups and staff interviews. The surveys were distributed to all students present, along with ethics information sheets and consent forms, in the second or third last lecture of the semester. Prior to the survey, an announcement containing the time and location of the focus group was posted in each unit's Blackboard site (the Faculty's learning management system).

Survey data was collected on scannable forms that were scanned through a quizscanner and the results exported to Microsoft Excel. A worksheet showed total figures for each response, the number of answers to that question and a percentage. Because the surveys were wholly voluntary and anonymous, not all students answered all questions. The focus group discussions and interviews were audio recorded and transcribed by an independent company. Focus groups were kept to half an hour wherever possible, and each participant was given an incentive (movie tickets or a voucher) to participate. Interviews were done with the academic coordinators of the units of study. The academic coordinators of each unit of study chose the topic of their podcast and how they intended them to be used by students, based on their impressions of what was needed to complement the learning and teaching resources and activities in their unit of study. The researchers grouped the podcast approaches together based on those descriptions, prior to analysing students' perceptions about the podcasts.

Survey data was analysed using Microsoft Excel. The focus group and interview transcripts were imported into QSR NVivo and open coding was performed, following a grounded theory approach, to put phrases into descriptive nodes (Glaser, 1992, p. 39). Summaries of each unit of study were generated, and then grouped into the broad podcast approach the lecturer described. The qualitative and quantitative data were also re-grouped accordingly to allow comparison between approaches.

\section{Findings}

This section reports the findings of the research questions. These findings are based on the student survey results, focus group discussions, and lecturer interviews. Other findings are also reported, highlighting some unexpected outcomes, many relating to the technological and pedagogical design of podcasts.

\section{What are the different approaches to podcasting to students used by teachers?}

Descriptions of the twenty types of podcasts, as identified by the academic creators of the podcasts, were compared and broken down into three broad categories based on similarities of approach:

1. Re-framed approach - Content presented in multiple media, such as via paper handout and podcast. Examples include: textbook chapter summaries, administrative content in podcast and paper handout.

2. Complementary - Information complementary to other learning and teaching activities (i.e., supportive content that may help some students, but not all students). Examples include: discussion of main points of the lecture broadcast before or after the lecture.

3. Supplementary - Non-compulsory information that supports learning and teaching activities, particularly assessments (i.e., supportive content that will help all students). Examples include: introduction to required readings, administrative 
content, study skills, questions frequently asked by students, content summaries (instead of lectures to allow for in-class discussion).

\section{Does the podcasting approach impact the students' use of the podcast?}

The survey asked students whether they listened to their lecturer's podcast. Overall, most $(69 \%)$ students said they listened to their lecturer's podcast; however when breaking down the results into types of podcast, early indications about how students used the podcasts became evident (Table 2).

Table 2: I listened to my lecturer's podcast $(\mathrm{N}=1748)$

\begin{tabular}{|l|c|c|}
\hline \multicolumn{1}{|c|}{ Type } & Yes & No \\
\hline Re-framed & $50 \%$ & $50 \%$ \\
\hline Complementary & $67 \%$ & $33 \%$ \\
\hline Supplementary & $76 \%$ & $24 \%$ \\
\hline Total & $69 \%$ & $31 \%$ \\
\hline
\end{tabular}

In terms of how the podcasts impacted students' learning, three questions from the survey addressed three important learning and teaching-related aspects: support or enhancement of learning, active engagement and feedback (Table 3).

Table 3: Student perceptions of podcast outcomes

\begin{tabular}{|c|c|c|c|c|}
\hline Item & Category & $\begin{array}{c}\text { Strongly agree } \\
\text { and Agree }\end{array}$ & $\begin{array}{c}\text { Disagree and } \\
\text { Strongly disagree }\end{array}$ & $\begin{array}{c}\text { Not } \\
\text { applicable }\end{array}$ \\
\hline \multirow{4}{*}{$\begin{array}{l}\text { My lecturer's podcast } \\
\text { supported / enhanced my } \\
\text { learning }(\mathrm{N}=1785)\end{array}$} & Re-framed & $59 \%$ & $14 \%$ & $27 \%$ \\
\hline & Complementary & $71 \%$ & $13 \%$ & $16 \%$ \\
\hline & Supplementary & $76 \%$ & $11 \%$ & $13 \%$ \\
\hline & Total & $71 \%$ & $12 \%$ & $16 \%$ \\
\hline \multirow{4}{*}{$\begin{array}{l}\text { My lecturer's podcast } \\
\text { helped me actively engage } \\
\text { with the material and / or } \\
\text { my class }(\mathrm{N}=1788)\end{array}$} & Re-framed & $55 \%$ & $17 \%$ & $28 \%$ \\
\hline & Complementary & $62 \%$ & $15 \%$ & $22 \%$ \\
\hline & Supplementary & $69 \%$ & $16 \%$ & $15 \%$ \\
\hline & Total & $65 \%$ & $16 \%$ & $19 \%$ \\
\hline \multirow{4}{*}{$\begin{array}{l}\text { My lecturer's podcast } \\
\text { provided feedback on my } \\
\text { learning }(\mathrm{N}=1782)\end{array}$} & Re-framed & $36 \%$ & $28 \%$ & $36 \%$ \\
\hline & Complementary & $31 \%$ & $41 \%$ & $27 \%$ \\
\hline & Supplementary & $60 \%$ & $22 \%$ & $17 \%$ \\
\hline & Total & $51 \%$ & $12 \%$ & $23 \%$ \\
\hline
\end{tabular}

\section{What perceived benefit did the podcast have for learning and teaching?}

Students were asked why they listened to their unit of study podcast (Table 4). Most students said they listened to reinforce key points $(25 \%)$, however the type of podcast seemed to impact how students said they used the resource. For example, most students using re-framed podcasts said they listened for exam revision, while most students using supplementary podcasts said they did so to reinforce information for assessment.

Students were also asked whether they appreciate the flexibility of podcasting (Table 5 ), and most students $(71 \%)$ agreed that they do. Comments from the focus group support this finding: 
I'm from China and I'm an international student... Because I have an $i P o d$, I can just download it, you can subscribe to the broadcast, and you don't have to worry about downloading because it will download automatically. And then you just use your iPod and can listen as many times as you want. Like, for us, if it's not easy to understand, we can listen many times.

Table 4: Why students said they listened (select all that apply) $(\mathrm{N}=2430)$

\begin{tabular}{|l|c|c|c|c|}
\hline \multicolumn{1}{|c|}{ Item } & Re-framed & Complementary & Supplementary & Total \\
\hline To prepare for class each week & $7 \%$ & $12 \%$ & $9 \%$ & $9 \%$ \\
\hline To revise for exams & $28 \%$ & $14 \%$ & $15 \%$ & $18 \%$ \\
\hline To replace lectures & $6 \%$ & $3 \%$ & $3 \%$ & $4 \%$ \\
\hline To reinforce information for assessment & $9 \%$ & $21 \%$ & $27 \%$ & $22 \%$ \\
\hline Because the content was complex & $7 \%$ & $8 \%$ & $6 \%$ & $7 \%$ \\
\hline Because English is not my first language & $11 \%$ & $13 \%$ & $11 \%$ & $11 \%$ \\
\hline Because I have difficulty hearing & $6 \%$ & $7 \%$ & $5 \%$ & $5 \%$ \\
\hline To reinforce key points & $26 \%$ & $23 \%$ & $24 \%$ & $25 \%$ \\
\hline
\end{tabular}

Table 5: I like podcasts because I use in my own time $(\mathrm{N}=1752)$

\begin{tabular}{|l|l|}
\hline Strongly agree and Agree & $71 \%$ \\
\hline Disagree and Strongly disagree & $17 \%$ \\
\hline Not applicable & $12 \%$ \\
\hline
\end{tabular}

\section{Do students and lecturers like podcasting?}

Most students using podcasts agreed that they would like to continue to have access to the resource (Table 6), and that they would like to be able to be able to use podcasting in other units of study at University (Table 6). Focus group comments backed this up: "I hope that every unit can use it...", "I would certainly like it to continue." and "I would recommend like almost all the lecturers to use it."

Table 6: Do students and lecturers like podcasting?

\begin{tabular}{|l|l|c|c|c|}
\hline \multicolumn{1}{|c|}{ Item } & \multicolumn{1}{|c|}{ Category } & $\begin{array}{c}\text { Strongly agree } \\
\text { and Agree }\end{array}$ & $\begin{array}{c}\text { Disagree and } \\
\text { Strongly disagree }\end{array}$ & $\begin{array}{c}\text { Not } \\
\text { applicable }\end{array}$ \\
\hline \multirow{2}{*}{$\begin{array}{l}\text { Overall, I recommend that } \\
\text { the lecturer keeps using } \\
\text { short podcasts (N=1750) }\end{array}$} & Re-framed & $76 \%$ & $8 \%$ & $16 \%$ \\
\cline { 2 - 5 } & Complementary & $76 \%$ & $12 \%$ & $12 \%$ \\
\cline { 2 - 5 } $\begin{array}{l}\text { I would like to see } \\
\text { podcasting used in other } \\
\text { units of study (N=1774) }\end{array}$ & Supplementary & $82 \%$ & $10 \%$ & $8 \%$ \\
\cline { 2 - 5 } & Re-framed & $81 \%$ & $6 \%$ & $13 \%$ \\
\cline { 2 - 5 } & Supplementary & $79 \%$ & $9 \%$ & $9 \%$ \\
\hline
\end{tabular}

\section{Other findings}

Students own relevant equipment

Students were asked whether they own an MP3 player (e.g. iPod) in the survey (Table 7 ) and whether they had the equipment and experienced any difficulty in the focus groups. Most students (85\%) said they own an MP3 player (Table 7). Focus group comments support this: "I listened at home on my computers. I had no problems with downloading anything." and "I had everything."

Table 7: Proportion of students who say they own an MP3 player $(\mathrm{N}=1792)$

\begin{tabular}{|l|l|}
\hline Yes & $85 \%$ \\
\hline No & $15 \%$ \\
\hline
\end{tabular}


Easy to use

Regardless of how students defined podcasting or whatever misunderstandings they had, they found the technology easy to use. Despite a 'how to' guide being available, many students did not read it, and their experience was that "it just happened... it was very easy." Most students in the focus groups agreed that using podcasts was easy because "... it was pretty basic and well set out... I didn't really need any technical skills."

New users to the technology similarly seemed to not be affected by their lack of technical savvy: "This was my first experience, and I wasn't sure whether my computer set up at home or at work would actually do it. So I was really quite surprised at how easy it was to do it."

\section{Diverse media}

Having a range of learning and teaching resources available is important to students. Students from units using all three podcast types mentioned it in some way in the focus groups. For example, "I reckon it's just like when you have too much of one thing you want something else. So because we have so much reading to do that we want podcasts... I reckon you need a good balance" and "It's a nice change from having to just read, read, and read." Students also recognised that a balance between different media was important, warning that if one format dominated others, the appeal would diminish: "As long as it didn't become overused... because as soon as it becomes overused people just stop [using it]."

\section{Voice}

The focus group discussions highlighted the importance of voice. One of the re-framed content podcasts was recorded by a professional media presenter, rather than the lecturer (although it was scripted by the lecturer). This provoked some interesting responses from the students: "I think it's ... intimidating, ... a little scary"; "I would like to see the lecturer do it because it gives us the confidence. If someone else is doing it, you don't know how much you must trust it."

Discussions with students in the other podcast groups supported students' preference for their lecturer's informal tone:
I think you can say a good podcast isn't an audio book, a good podcast would be speaking to an audience... So as long as you're speaking to the audience and you're understanding that you've seen them face-to-face and you know how they think and how they can react you can speak to them. But if you're just reading notes, you may as well just give me the notes on paper and I'll read it to myself.

This contradicts the lecturers' reasonable expectation that a professional recording would be better: "I think the professionally made ... [podcast episodes] are far better than anything that a lecturer can do. These people, that's their job... we're not professionals at doing that so we stay out of [it]."

Furthermore, students from the supplementary and re-framed content groups seemed to consider their lecturer's podcasts to be a very personal form of communication: "... with podcast, it is more personal, I think. You can literally speak to the student"; “... I found it really nice. It was like one on-one, kind of thing." This is feedback that was not anticipated, but could be both comforting to lecturers who are nervous about creating a podcast, while also being crucial to the success of using podcasting in higher education. 
Episode length

There is little consensus between students on what the ideal length of a podcast episode should be. Some felt that "the length of a song" would be ideal, while others found that the episodes that presented "concepts in ten, fifteen minutes ... (is what) kind of attracted me to it." None of the students in the group that had twenty-minute podcast episodes reported a problem with the length, while others thought "anything over 15 minutes is just pushing it a little bit." Some students listened because the episodes were short: "I listened to it because [the lecturer] was saying... how it's really short, and that kind of appealed to me because I'm from the science faculty, and the podcasts there were full lectures - it's like a whole hour and it's really intense - but here I get the intro concepts in ten, fifteen minutes, which kind of attracted me to it." No student reported that they wanted longer podcast episodes.

Podcasting should be contextual

Another issue raised by students in the focus group discussions suggests that podcasting cannot be generalised to suggest that the technology will benefit students, but that it depends on the need in the unit of study. When asked whether podcasting should be embedded in other units of study, one student replied that "It depends on the lecture and the way that it's conducted, but certainly for this type of one that we've just done." Similarly, another student recognised the need for the particular podcast that their lecturer began to produce part of the way into the semester:

[In the lecture] you're being told what this author is going to do and you don't know who the author is, you haven't printed off his reading, so you don't have it there to look at and you're supposed to be trying to remember this stuff so that you can look at it - it didn't work at all. It was only once you put the podcast up that I could actually make use of that information.

Taking the context into account then, by acknowledging that it would be more beneficial for that resource to be podcast than approached in the face to face time, highlights the situated nature of learning and cognition.

Benefits for students from non-English speaking backgrounds A number of non-English speaking background students mentioned benefits for them during the focus groups. Some said that being able to listen to their lecturer multiple times allowed them to understand words they otherwise might have missed: "I could listen to the podcasts for those sentences that I could not get twice or three times." Others said that they thought the podcast would help them develop their language skills: "It was also helpful to develop my listening skills in terms of English."

\section{Suggested podcasting improvements}

Students in the focus groups were asked whether they had any suggestions for improvement for future podcasting (Table 8). Of 278 comments, $18 \%$ of those expressed a desire to have recorded lectures, $17 \%$ wanted different information to that presented elsewhere - particularly those listening to re-framed podcasts - and $12 \%$ wanted shorter, more concise podcast episodes.

\section{Staff perceptions}

The teaching staff were positive about their experience podcasting. Benefits cited varied from the technical ease of creating audio-only podcast episodes: “...I'm a bit of a technophobe... I don't always find that the dividend pays off... but this time, I 
definitely did. It was very easy to use. It's very user-friendly"; to being able to deliver something useful to students: “...we're run off our feet... [Podcasting] is not a big deal. I think it you had to weigh up the pros and cons there's definitely more pros"; and workload: "...even though it was an extra half hour each week, it's a relatively small cost for what is potentially quite a big benefit. So in terms of workload, I don't think it's a huge imposition... and [for a] pure, audio-only podcast, it is reasonably straight forward and not all that time-consuming to do." One lecturer commented that podcasting better enabled her to manage face to face time with students:

I would like to think that the class time is too valuable for one person to be talking. It's time for people to apply and work together. So if you can take away that element of me standing there - because there's always a need for that, students want that, they want the guidance and they want the explanation - but then the class time can be used more effectively to apply the information. I think for that, I think podcasting is of great value.

Table 8: Suggested improvements $(\mathrm{N}=278)$

\begin{tabular}{|l|c|}
\hline Record the lecture & $18 \%$ \\
\hline Different information (to what's already in the lecture/text) & $17 \%$ \\
\hline Shorter, more concise podcast episodes & $12 \%$ \\
\hline Reiterate main points to the lecture & $9 \%$ \\
\hline More detail in new podcast episodes & $8 \%$ \\
\hline Different voice (less formal, not too fast) & $6 \%$ \\
\hline Slides and audio (enhanced) podcast & $6 \%$ \\
\hline Podcasts from industry people & $4 \%$ \\
\hline More frequent episode broadcasts & $3 \%$ \\
\hline Podcast frequently asked questions & $3 \%$ \\
\hline Podcast teaser episodes (for next lecture/whole unit of study) & $2 \%$ \\
\hline Re-record podcasts for each semester (i.e., don't re-use last semester's podcast) & $2 \%$ \\
\hline More references & $2 \%$ \\
\hline Podcast differences in content between streams/lectures & $2 \%$ \\
\hline Video and audio (vodcast) & $1 \%$ \\
\hline Better audio quality & $1 \%$ \\
\hline Transcripts or audio/text & $1 \%$ \\
\hline
\end{tabular}

\section{Discussion}

\section{Easy to use, easy to create}

Creating learning and teaching objects can be a time-consuming process that requires careful design and a high standard result. It may be that such objects - due to time constraints - can only ever be created weeks, even months or years, before they are used, restricting flexibility (Henry \& Meadows, 2008). Teaching academics, however, found the creating of short, audio-only podcast episodes so easy, that they were able to create them as required to respond to a need in the classroom, or give important information that they did not have time to go through in a lecture.

Students were offered a guide and technical support during business hours for listening to podcasting, yet only a handful of students seemed to take advantage of either. At Graz University of Technology, Austria, researchers emphasised that for a resource to be effectively used by students it must be easy to use (Ebner, Holzinger \& Maurer, 2007). Furthermore, eighty-five percent of participating students among all twenty units of study own an MP3 player. This is supported by the IMPALA pilot 
study in the UK which found that students owned some kind of device that played MP3 files (Edirisingha \& Salmon, 2007). As suggested by this study, students have the appropriate equipment and confidence to be able to use podcasts, and podcasting is a reasonably easy thing to do.

\section{Flexibility}

Students in this study reported they liked podcasting because it enables flexible learning. Podcasting, which has the potential for mobile use, is the ultimate flexible learning resource as it may be used while in transit, but is not restricted to mobile use. There are a number of ways that students utilised the flexibility of podcasting in this study. On a surface level, students reported valuing the ability to re-listen or modify the pace at which they listen as desired. Being able to design their own study context, however, could better prepare students for lifelong learning.

If taking a constructivist approach to media (Jonassen, Campbell \& Davidson, 1994), it is important for students to choose the physical (where) and mental (when, at what pace) context for their study, rather than be in a controlled learning environment such as a computer lab or lecture theatre. In providing a tool that is flexible enough to be used in a variety of ways, students are able to make decisions about, and be aware of, their own learning (Sawyer, 2006, p. 2). Flexible aspects of podcasting include how it might be used (such as alongside slides, video, readings and diagrams), and how the activity of using it can vary (such as considering the pace, and appropriate time and place to listen). Furthermore, it creates the possibility for the development of distributed intelligence, rather than a passive, transmission of knowledge medium (Jonassen et al., 1994; Lim, 2006). Podcasting allows students to make decisions holistically about the learning context that most suits them. More than being purely electronic or mobile, offering students the flexibility to construct their learning in this way (the importance of which is highlighted by Low \& O'Connell, 2006) is a significant benefit.

Collis and Moonen (2002) suggest that the more flexible and active a resource is, the more likely it is to facilitate learning (that is, less versus more flexible, acquisition versus active contribution). In this study, the re-framed content podcasts were flexible, but they concerned the transmission and acquisition of knowledge. The complementary podcasts were similarly very flexible, but possibly a little further along toward being more active, as they helped students contextualise knowledge as well as confirm the acquisition of lecture material. The supplementary podcasts however, were flexible, but involved a great deal more action on students' part as they were linked with doing readings, preparing for assessment and understanding knowledge. Considering podcasting in light of Collis' and Moonen's flexibility-activity framework could be a useful way to consider future design of such resources.

\section{Voice}

An unexpected finding from this study is that the voice in the digital audio file is important. Students liked the informal, relaxed tone of their lecturer speaking to them. They describe this as "personal" and said it made them feel they were having some kind of "one on one" consultation with their lecturer. This is supported by research about the use of audio in distance education that highlights that emotive emphasis that can be portrayed by the human voice, and how that can help give shape to learning and construct connections between the learner/listener and teacher/speaker (Power, 
1990). Furthermore, students said they felt the lecturer is the "expert", and many want to hear about what their lecturers have to say. In contrast, when a professional presenter gave the podcast, students did not like the voice or tone because it sounded unnatural, and they did not trust the unknown voice. There is still great interest in recording lectures, as recent research suggests (e.g., Larkin, 2010; McGarr, 2009; Scutter, Stupans, Sawyer \& King, 2010).

\section{Content design}

This study aimed to allow teaching staff to elect a perceived need in their unit of study that they thought a podcast might address and included a range of approaches to creating content. Each podcasting approach was originally intended to meet a requirement that the staff member hoped would create a balanced pedagogy for their unit of study, such as allowing the workshop style, face to face time to flourish by podcasting less-crucial instructional content, such as information about critical writing and the final exam. Student responses to why they used their lecturer's podcast in this study suggested that the intention for creating the podcast was recognised and the resource used as intended. Most students using complementary podcasts said they listened to reinforce main points, while most students listening to supplementary podcasts said they did so to reinforce concepts for assessment tasks (Table 4). This is supported by Evans' (2008) study, which found that a podcast designed to deliver a series of revision 'snapshots' provided students with helpful revision tools. Kirkwood and Price (2005) remind educators that for students to be able to create meaning from learning resources, those resources should be designed to help students meet specific educational goals and, as listed above, each podcast was created with a pedagogic intention, which the findings showed students recognised. This confirms the need for a learning and teaching-related need when creating a learning resource, rather than only a technological-related advantage (McGarr, 2009).

\section{Conclusion}

Positive learning and teaching experiences come from the teaching (not just the technology) and technologies, such as podcasting, work best when integrated with pedagogy (Henry \& Meadows, 2008). It is unsurprising that teaching objects become learning objects for students when they have a close fit to the learning activities designed by the teaching staff. In this case, this includes supplementary podcasts that relate to assessment tasks and preparation for assessment tasks, and podcasts that extend knowledge acquired from readings and practised in the classroom.

\section{Limitations and future research}

This study contains a number of aspects with possible bias, such as sampling (students self-selecting due to the voluntary nature of participation), survey design (not considering all possible kinds of data, such as students' postgraduate/ undergraduate status) and data analysis (not including students' marks).

Possible avenues of future research might include investigation into any pedagogical benefits of lecture recording with consideration about the apparent lack of interest that students in this study had with podcasts of re-framed content. This study suggests that further research into the use of digital media by non-native speakers is likely to be a worthwhile endeavour, especially where there are often high proportions of international and non-native speakers in units of study. This study suggests that being 
able to re-listen to content is useful to students generally, but a more focused study could produce results specific to a student demographic.

\section{Acknowledgments}

Initial funding was gratefully received from the Apple University Consortium, courtesy of Dr Mary Peat and project manager, Karen Scott. Further funding was provided by the University of Sydney Teaching Innovation and Equipment Scheme. This study could not have been completed without the cooperation and willingness to innovate on the part of the participating teaching staff and students.

\section{References}

Aldrich, D., Bell, B. \& Batzel, T. (2006). Automated podcasting solution expands the boundaries of the classroom. In 34th Annual ACM SIGUCCS 2006 Conference Proceedings, (pp.1-4). Edmonton, Canada, 5-8 November.

Belanger, Y. (2005). Duke University iPod first year experience final evaluation report. Durham, NC, USA: Duke University. [viewed 5 Sep 2009]

http: / / cit.duke.edu/pdf/reports / ipod_initiative_04_05.pdf

Bell, T., Cockburn, A., Wingkvist, A. \& Green, R. (2007). Podcasts as a supplement in tertiary education: An experiment with two computer science courses. In D. Parsons \& H. Ryu (Eds), Mobile Learning Technologies and Applications (MoLTA) 2007 (pp. 70-77). Massey University, New Zealand, 19 February. http:/ / molta.massey.ac.nz/massey/fms/Molta/Bell.pdf

Brittain, S., Glowacki, P., Ittersum, J. V. \& Johnson, L. (2006). Podcasting lectures. EDUCAUSE Quarterly, 29(3), 24-31. http:/ / net.educause.edu/ir/library/pdf/ eqm0634.pdf

Calder, A. (2006). If you can't beat 'em, podcast 'em! In 10th Pacific Rim First Year in Higher Education Conference 2006. Griffith University, Gold Coast, Australia, 12-14 July. http: / / www.fyhe.com.au/ past_papers / 2006/Nuts\%20\&\%20Bolts /Calder.pdf [viewed 5 Sep 2009, verified 9 May 2010].

Chan, A., Lee, M. J. W. \& McLoughlin, C. (2006). Everyone's learning with podcasting: A Charles Sturt University experience. In Who's learning? Whose technology? Proceedings ascilite Sydney 2006. http:/ / www.ascilite.org.au/conferences/sydney06/proceeding/pdf_papers/p171.pdf

Collis, B. \& Moonen, J. (2002). Flexible learning in a digital world. Open Learning: The Journal of Open and Distance Learning, 17(3), 217-230.

Ebner, M., Holzinger, A. \& Maurer, H. (2007). Web 2.0 technology: Future interfaces for technology enhanced learning? Universal Access in HCI (UAHCI 2007), 559-568.

Ebner, M., Nagler, W. \& Saranti, A. (2007). TU Graz goes podcast. In M. Lindner \& P.A. Bruck (Eds.), Micromedia and corporate learning: Proceedings of the 3rd International Microlearning 2007 Conference (pp.221-233). Innsbruck, Austria, 21-22 June. [verified 9 May 2010] http:/ / lamp.tugraz.ac.at/ i203/ebner / publication/07_microlearning.pdf

Edirisingha, P. \& Salmon, G. (2007). Pedagogical models for podcasts in higher education. http:/ / hdl.handle.net/2381 / 405 [verified 9 May 2010].

Egeneldt-Nielsen, S. (2005). Beyond edutainment: Exploring the educational potential of computer games. Doctoral Thesis, IT-University of Copenhagen, Denmark.

Evans, C. (2008). The effectiveness of m-learning in the form of podcast revision lectures in higher education. Computers $\mathcal{E}$ Education, 50, 491-498. 
Franklin, M. \& Zdonik, S. (1998). "Data in your face": Push technology in perspective. In L. M. Haas \& A. Tiwary (Eds.), Proceedings ACM SIGMOD International Conference on Management of Data. Seattle, Washington, 2-4 June. [verified 9 May 2010]

http: / / www.eecs.berkeley.edu / franklin/ Papers/ datainface.pdf

Glaser, B. (1992). Basics of grounded theory analysis. Mill Valley, California: Sociology Press.

Gunn, C., Woodgate, S. \& O'Grady, W. (2005). Repurposing learning objects: A sustainable alternative? ALT-J, 13(3), 189-200. http:/ / repository.alt.ac.uk/96/

Henry, J. \& Meadows, J. (2009). An absolutely riveting online course: Nine principles for excellence in web-based teaching. Canadian Journal of Learning and Technology, 34(1). [viewed 5 Sep 2009]. http:/ / www.cjlt.ca/index.php/cjlt/article/view / 179/177

Jonassen, D., Campbell, J. \& Davidson, M. (1994). Learning with media: Restructuring the debate. Educational Technology, Research \& Development, 42(2), 31-39.

Kirkwood, A. \& Price, L. (2005). Learners and learning in the twenty-first century: What do we know about students' attitudes towards and experiences of information and communication technologies that will help us design courses? Studies in Higher Education, 30(3), 257-274.

Larkin, H. E. (2010). “But they won't come to lectures...” The impact of audio recorded lectures on student experience and attendance. Australasian Journal of Educational Technology, 26(2), 238-249. http:/ / www.ascilite.org.au/ajet/ajet26/larkin.html

Lee, M. J. W., McLoughlin, C. \& Chan, A. (2007). Talk the talk: Learner-generated podcasts as catalysts for knowledge creation. British Journal of Educational Technology, 39(3), 501-521.

Lim, K. Y. T. (2006). Now hear this - exploring podcasting as a tool in geography education. http: / / homepage.mac.com/voyager/brisbane_kenlim.pdf [viewed 5 Sep 2009, verified 9 May 2010].

Low, L. \& O'Connell, M. (2006). Learner-centric design of digital mobile learning. Paper presented at the OLT Conference, Learning on the Move. Queensland University of Technology, 26 September. http:/ / online.cit.act.edu.au/mlearning/lowoconnell2006.pdf [viewed 5 Sep 2009, verified 9 May 2010].

McGarr, O. (2009). A review of podcasting in higher education: Its influence on the traditional lecture. Australasian Journal of Educational Technology, 25(3), 309-321. http: / / www.ascilite.org.au/ajet/ajet25/mcgarr.html

Neuman, W. (2006). Social research methods: Qualitative and quantitative approaches (Sixth ed.). Boston: Pearson Education Inc.

Power, D. (1990). The use of audio in distance education. In S. Timmers (Ed), Training needs in the use of media for distance education (pp. 43-60). Singapore: Asian Mass Communication Research and Information Centre.

Sawyer, R. K. (2006). The new science of learning. In R. K. Sawyer (Ed.), The Cambridge handbook of the learning sciences (pp. 1-16). New York: Cambridge University Press.

Schlosser, C. A. \& Burmeister, M. L. (2006). Audio in online courses: Beyond podcasting. Paper presented at the World Conference on E-Learning in Corporate, Government, Healthcare and Higher Education. http: / / www.nova.edu/ burmeist/audio_online.html [viewed 5 Sep 2009, verified 9 May 2010].

Scutter, S., Stupans, I., Sawyer, T. \& King, S. (2010). How do students use podcasts to support learning? Australasian Journal of Educational Technology, 26(2), 180-191. http: / / www.ascilite.org.au/ajet/ajet26/scutter.html 
Shannon, S. (2006). Why don't students attend lectures and what can be done about it through using iPod nanos? In Who's learning? Whose technology? Proceedings ascilite Sydney 2006. http: / / www.ascilite.org.au/conferences / sydney06/proceeding/pdf_papers/p28.pdf

Tynan, B. \& Colbran, S. (2006). Podcasting, student learning and expectations. In Who's learning? Whose technology? Proceedings ASCILITE Sydney 2006.

http: / / www.ascilite.org.au/conferences/sydney06/proceeding/pdf_papers/p132.pdf

Wheeler, M. (2009). Developing the Media Zoo in Second Life. British Journal of Educational Technology, 40(3), 427-443.

Lucy Taylor, Acting Research and Quality Manager, Office of Learning and Teaching in Economics and Business (OLTEB), Faculty of Economics and Business, The University of Sydney. Email: 1.taylor@sydney.edu.au

Dr Steve Clark, Educational Designer, The Royal College of Pathologists of Australasia Surry Hills, NSW 2040, Australia. Email: stevec@rcpa.edu.au 